\title{
Naming Patterns among Northern Sotho, Xitsonga and Tshivenda Communities of SA: Religio-cultural Perspective
}

\author{
Mokgale A. Makgopa \\ https://orcid.org/0000-0002-8056-1195 \\ University of Venda, South Africa \\ Mokgale.Makgopa@univen.ac.za
}

\author{
Temba T. Rugwiji \\ https://orcid.org/0000-0002-9080-9908 \\ University of South Africa \\ rugwiji1964@gmail.com
}

\begin{abstract}
This study discusses naming patterns and practices of three South African indigenous groups as representative examples, namely Northern Sotho, Xitsonga and Tshivenda, from a religio-cultural perspective. In almost every African culture and tradition, newly-born babies receive their names immediately after birth. Names are usually predetermined when the mother is pregnant. Although in numerous instances the parents are responsible for naming the baby, family members (e.g., aunts, grandparents, brothers, or sisters) may also suggest a name. The naming of babies is not a random exercise because religio-cultural meanings are attached to a name. By utilising a narrative approach as a method, the article argues that indigenous names carry meanings, and each name tells a story. The study aims at demonstrating that names play a significant role in the preservation, documentation and promotion of cultural heritage. The discussion commences by exploring naming patterns from a biblical perspective in order to provide a matrix for a religio-cultural thrust of child-naming within the aforementioned South African indigenous groups.
\end{abstract}

Keywords: South African communities; naming patterns; indigenous names; African cultural heritage

\section{Introduction}

Borkfelt $(2011,116)$ argues that the act of naming is among the most basic actions of language. Borkfelt further remarks that it is indeed naming something that enables us to communicate about it in specific terms, whether the object named is human or nonhuman, animate or inanimate (Borkfelt 2011, 116). Names identify individuals. The name defines an individual's position in his family and in society at large; it defines his social responsibility and classifies a person (Wilson 1998, xii). Birth names are the 
names children receive immediately after birth (Mphela 2010, 29). In the Northern Sotho communities of Limpopo, for instance, as Mphela (2010) observes, grandparents, aunts, uncles and other family members are the ones accountable for the giving of names. Guma's research on names and naming in South Africa informs this study in a way as well, for example where he says, "names are more than a word or words by which a person, animal, place or thing is known ..." (Guma 2001, 265). Names are always differentiated into two major categories: 1) the surname (others refer to it as "the last name"); and 2) the given name (referred to as the "first name" or "Christian name"). Christian names - the bulk of which derives from the Hebrew Bible (HB) - include: Adam=earth; Abel=breath; Abraham=father of nations; Aaron=light bringer; Micah=who is like God? Miriam=bitterness; Agnes=pure, among others. In many cases, most Bible names are theophoric - they derive from "God." Similarly, among the Basotho of southern Africa, naming children after events may serve the psychological and emotional needs of the society or family (Guma 2001, 269) because personal names are unique and meaningful, emerging from circumstances at the time of the child's birth (Mutunda 2016, 75). Differentiation between the two types of names is that the surname, which is sometimes referred to as the last name, is inherited and always used to identify with a group of people who might be related. Jobling (2001, 353) remarks that "hereditary surnames contain information about relatedness within populations." It is inherited with the clan, though sometimes it may be changed, depending on the circumstances that the group might be faced with. Thus, Neethling $(2004,1)$ maintains that "the names express some sort of expectation or aspiration from the name givers for the child." Therefore, a surname or last name forms a central part of genealogy since it demonstrates some lineage or links within the clan. Surnames evoke much interest in genealogy since certain names given to a clan has got some links with the history of a clan. Perhaps it is the same line of thinking that motivated Patrick Hanks to also admit that "Each of us has a family name, generally inherited via our parents from our forebears, traditionally through the male line."

Concerning the given name or first name, there are various reasons why a child is given a specific name. Normally, the first question that is always asked is, where does the name come from? The meaning attached to the name plays a significant role since names are not given lightly as they represent thoughts, feelings, emotions and history. Thus, Guma $(2001,267)$ is correct when he remarks that the names given to individuals refer to historical events, experiences, emotions, status relations, clan and kinship relations, as well as authority. Usually, in genealogy, much interest is vested in the following, people, places, history, time and periods. Therefore, naming patterns and customs vary from culture to culture. The principal aim of this article is to make a random survey on the naming patterns and customs as practised by Black South Africans. The article will specifically focus on the given name, as it would like to share the following patterns in

1 Patrick Hanks, n.d. “General Information.” Accessed February 24, 2017.

https://www.casa.ucl.ac.uk/surnames/papers/Hanks_background.pdf. 
giving names: repetition, duplication, frequency, virtue and recycled. The present study seeks to respond to the following three research questions:

- How is naming practised within South African communities?

- How do cultural beliefs and practices affect naming?

- Did the advent of Western culture, the Jewish tradition and the Christian missionary church affect naming patterns among Black South Africans?

\section{Statement of the Problem}

The present study derives from the following two main problems which have been identified.

First, admittedly, voluminous literature has been published on names and naming among three South African ethnic groups, namely Northern Sotho, Xitsonga and Tshivenda. This approach has been influenced particularly by the negative roles played by Western culture, the Jewish tradition and the Christian missionary church in terms of re-orienting Black South Africans by suggesting some changes to their names. The present study encompasses such debates in a unique way.

Second, we are investigating phenomena of names and naming patterns in a postcolonial era in which name-changing of streets, cities, buildings, and/or personal names has become the norm. However, we are not unaware of the pitfalls that exist within our cultural naming patterns when the practice is "ritualised" in modern society. For example, a grown-up girl/boy has a democratic right to change their birth-names for a preferred new name. A name change, at this stage and in this context, is not influenced either by the modern church or contacts with the Western milieu.

\section{Methodology}

The present study utilises a narrative approach as a method, also called secondary data analysis (popularly known as desktop research). As noted by Frankel, Devers, and Kelly $(2000,5)$, the most useful guidelines for selecting a research method are based on the research questions one is asking and the extent to which the method will inform the research questions. Engagement with previous contributions on names and naming in South Africa has aided the reformulation of the present discourse. Representative examples are as follows: Guma (2001); Jobling (2001); Musere and Byakutaga (1999); Mutunda (2016); Neethling (2003; 2004); Nyambi, Mangena, and Pfukwa (2016); Pelczar (2001); Suzman (1994); and Tonkin (1980), among others.

\section{Theoretical Framework}

According to Smith (1974, 1727), assigning a name to a child is loaded with fundamental social meaning. Smith-Bannister (1997, 19), who agrees with Smith's opinion above, reiterates that a name defines a child as a Christian (or another group), 
classifies him as to gender, suggests a social status and even implies a time when he was born. Name-giving among the Xhosa of South Africa takes on other proportions than in a Euro-Western context (Neethling 2004, 1). Neethling $(2003,56)$ also observes that name meaningfulness continues to differentiate the naming patterns among South African communities from Western naming practices. The child may be given an indigenous name that describes the challenges that the family was faced with before the birth, at the time of birth or something anticipated for the future. Pelczar $(2001,133)$ maintains that names can and usually do vary in terms of what literal contents they express across the various contexts in which they get used. However, other indigenous names may express moments of joy and blessings, for example, Mahlatse (Northern Sotho), Phathutshedzo (Tshivenda) and Mikateko (Xitsonga). The indigenous names in three different South African ethnic groups mentioned above imply that the birth of the child brings joy and happiness within the family.

Scott (2004) remarks that in certain circumstances, the name of the child may reflect miseries or sometimes misunderstandings between the husband and wife or members of the family. Indigenous names like Dikeledi in Northern Sotho, Mihloti in Xitsonga and Matodzi in Tshivenda imply tears. Normally, when a child is given a name of this sort, it implies that his/her birth coincided with death in the family. Scott $(2004,225)$ further notes that certain circumstances that portray some mysteries within the family could lead to the naming of a child because marriage has fallen on hard times.

Generally, naming serves as socio-cultural elucidation of the concepts of "self," "person," and an "individual" within a society. Names embody individual life experiences, social norms and values, status roles and authority, as well as personality and individual attributes. A name identifies an individual with their kith and kin and distinguishes them from others. Indigenous names in South Africa intuitively relate to the fauna and flora.

\section{Names and Naming Patterns in the Hebrew Bible (Jewish tradition)}

The biblical text portrays that naming started with God. Mphela $(2010,2)$ maintains that in the Old Testament (Gen. 2:19), the names of individuals are meaningful. For example, Adam is named after the "earth" from which he was created. Among ancient Hebrew societies, child-naming was as critical as it is in our contemporary African societies. For Haber (2001), theophoric names derive from or include the name, God. The Hebrew Bible (HB) says more elaborately that "A good name is rather to be chosen than great riches, and loving favour rather than silver and gold" (Prov. 22:1). The inscription in the table below shows the criticality of child-naming in ancient Israel. 


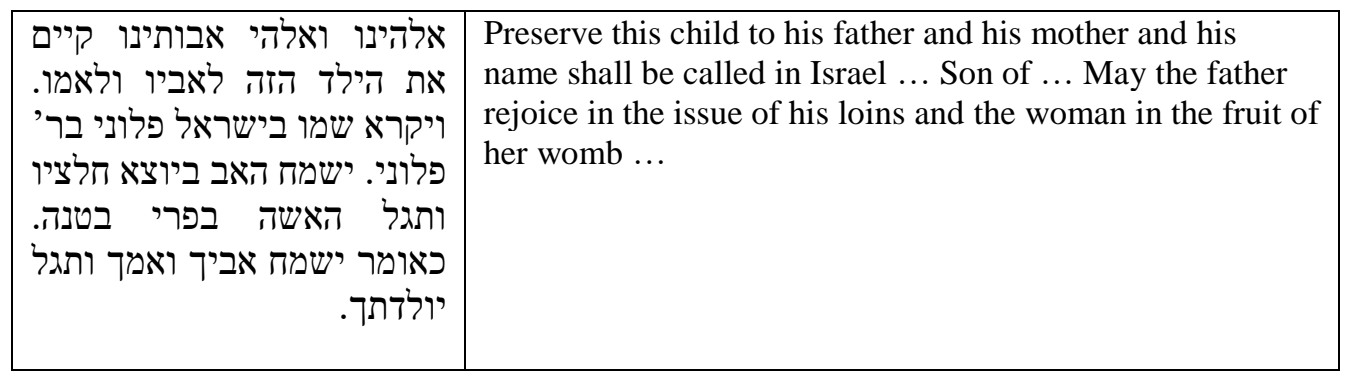

Figure 1: Criticality of child-naming in ancient Israel

Most Bible or Hebrew names are theophoric in character. Haber provides invaluable insights in this regard. Haber explains that theophoric names in the HB are names built largely by using the two Hebrew denominations of God, Elohim and the

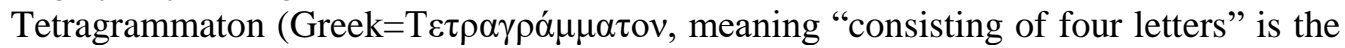
Hebrew theonym יהוה), commonly transliterated into Latin letters as YHWH ("the Lord") (see Knight and Levine 2011). Haber goes on to say that with Elohim, most names take only the first two letters, often at the beginning of the name (for example, Elkanah, Elkhanan, Eliezer, Eliah, Elyakim), or at the end (for example, Gabriel, Nethanel, Daniel, Raphael, Israel). Haber further explains that the Hebrew הָָָָ=hâyâh is a verb meaning "to be"; "to exist"; "to cause to become"; or "to come to pass." Hebrew names always had cultural/religious meanings of situations prevailing in societies in general and families. Figure 2 below shows representative examples:

\begin{tabular}{|l|l|}
\hline Name & Meaning \\
\hline Elijah & "God the Lord" \\
\hline Daniel & "Judgment of God" \\
\hline Elkanah & "God has purchased" \\
\hline Elisha & "God is salvation" \\
\hline Elizabeth & "God is my oath" \\
\hline Eliel & "My God is God" \\
\hline Elizur & "My God is a Rock" \\
\hline Ezekiel & "God strengthens" \\
\hline Jeruel & "Fear of God" \\
\hline Ariel & "Lion of God" \\
\hline Ishmael & "God listens" \\
\hline Hazael & "God has seen" \\
\hline Gabriel & "God is my strength" \\
\hline Reuel & "Friend of God" \\
\hline
\end{tabular}

Figure 2: Representative examples of Hebrew names

\section{Names and Naming Patterns in the New Testament (NT)}

When Waters (1984,161-162) says, "A good name is a thread tied around the finger to make us mindful of the errand we came into the world to do for our Master," in our opinion, he had Jesus in mind because Jesus is constantly referred to as a "Master" in the New Testament of the Bible. For example, adhon ("master" 1 Tim. 6:1; 2 Tim. 
2:21), which is rendered "Lord" (Luke 2:29); kurios ("Master"; "Lord"; "Sir" Matt. $1: 20 ; 6: 24 ; 15: 27 ; 23: 8$; Mark 13:35; Rom. 14:4). Jesus is also known by various titles such as Son of God, Son of Man, Son of David, Messiah, and Kyros, among others (Dreyer 2001, 507; Hahn 1974, 12). The birth name for Jesus was Immanuel, translated

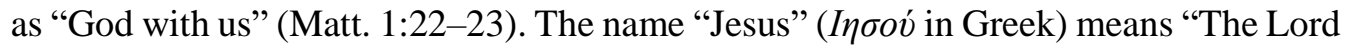
saves" or simply put, "Saviour"; hence "salvation" (Rugwiji 2014, 298). The name might have been common in ancient Israel because Jesus is referred to elsewhere as "Jesus of Nazareth" (John 1:45). Similar uses of identities that denote places of origin are "Simon of Cyrene" (Matt. 2:23; Luke 23:26) and "Joseph of Arimathea" (Matt. 27:57-60; Mark 15:43-46; Luke 23:50-55; John 19:38-42), among other examples. Sometimes ancient biblical people would be addressed by their profession or occupation. For example, John "the Baptist" (Matt. 3:1; 11:11) because he was an "immerser"/"baptiser." In the Gospel of Luke (1:59-61) we read of the controversy surrounding the name of the new-born baby who became known as John the Baptiser. Luke writes, "They called him Zacharias, after the name of his father. And his mother answered and said, 'Not so; but he shall be called John' (meaning 'Yahweh has been gracious'). And they said unto her, 'There is none of thy kindred that is called by this name'." The above dialogue shows that ancient societies valued highly both the cultural practices associated with names and the theophoric meaning of the name.

\section{Names and Naming in Christianity}

The meaning of the Greek word theophoros ${ }^{2}$ is "bearing or carrying a God." Onoma in Greek means "name." Theophoric nomata are names that derive from a God. A few examples of theophoric nomata from the New Testament Bible (which was originally Koine Greek) will help the reader, $\Theta \varepsilon o \varphi$ i ${ }_{0} \varsigma$ = Theophilus (Luke 1:3), meaning "friend of God." In Greek, $\theta \varepsilon \circ \varsigma$ (Theos) means "God" and pitos (philos) means "friend." The

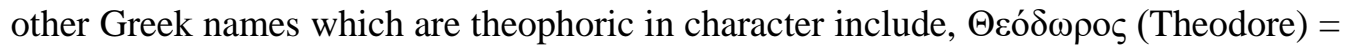

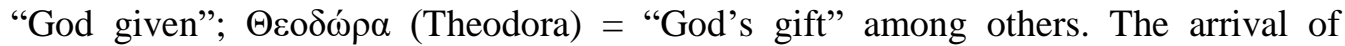
missionaries in Africa led to fundamental transformations in African social life and worldview. Arowolo (2010) subscribes to the above view by arguing that the era of colonial pillage and plunder led to the relative stagnation and often precipitous decline of traditional cultural pursuits in the colonies. The primary objective of the missionaries was to convert indigenous people to Christianity. Mphela $(2010,14)$ also remarks that in the Mbeere tradition, most people have Christian names in addition to given names. These Christian names were given to those who were baptised and to pupils attending missionary schools. Koma $(2012,22)$ concurs that the Northern Sotho people say that given English names that their children had many years ago were only given to the children by the time they went to school so that they would be granted permission to enter the school. Mphela $(2010,27)$ and Appiah $(2010,16)$ chronicle that children were given names which derived from the Bible to denote their newly acquired status, such as Samuel, Ruth, John, Isaiah, Mathews, and or Deborah, among others. Christian names were used to colonise the South Africans when the missionaries failed to 
pronounce indigenous names and ended up undermining them. It can further be problematised that another strategy for changing local names was to "Westernise" Black South Africans. Chitando $(2001,144)$ maintained that in the encounter between Western missionaries as propagators of the Christian gospel and African converts, the cultural significance of indigenous names inevitably surfaced. A family-given name is a name that is given to children after birth or when they begin school (Campbell and Campbell 1996). Koma $(2012,42)$ concurs that most of the given names in the past were in English. However, currently, South Africans are giving their children indigenous names based on a variety of factors, such as the advent of democracy.

\section{Names and Naming Patterns in South Africa}

Sesotho is a Bantu language of Southern Africa, spoken by more than two million people (Mohome 2013, 171). Most speakers of this language are found mainly in Lesotho, in the Orange Free State province, in the southern parts previously known as the Transvaal (that now includes the Free State Province), and in the north-eastern parts of the Cape Colony (now known as Eastern Cape Province) (Mohome 2013, 171). Sesotho is both a cultural and linguistic phenomenon in as much as culture and language are interdependent systems (Mohome 2013, 171). Among the Northern Sotho, Tsonga and Venda, a child may be named after a family member or relative. Common names as representative examples are, Makoma (Northern Sotho), Jamela (Tsonga) and Phophi (Venda). Other names are Mosepherere, Gebuza, Raphehli, Nwamaxoxo, Matobole, among many others. The name may either be from a paternal or maternal relative. There are also variances and commonalities in terms of naming patterns in Northern Sotho, Xitsonga and Tshivenda. Mandende $(2009,18)$ presupposes that intermarriage has had a great influence on Tshivenda cultural systems, including the system of personal naming. Owing to intermarriage, Mandende asserts, there are several Sesotho personal names found among the Vhavenda, such as Lerato ("love") and Ngwako ("house"; "courtyard"). According to Mandende (2009, IV), traditionally, Tshivenda personal names were chosen by the male grandparent or another senior male person, or the role was played by the father of the child. Mandende remarks that the mother of the child did not have any say in the selection or bestowal of a personal name. Whenever Africans choose a personal name, it bears a meaning, or it is the name of a deceased member of the family, adds Mandende. Indigenous Africans believe that there are always connections between the living and the dead and that the dead have a great influence on the lives of the living (Mandende 2009, IV). In the following sections, this study will discuss some examples of names and their categories as follows: names pertaining to cultural beliefs; names about family circumstances; bynames; occupational names; nicknames; pseudonyms; circumcision names; and teknonymous names.

\section{Names Pertaining to Cultural Beliefs}

Olatunji and Issah $(2015,81)$ have revealed that among the Basotho of South Africa, there are names that strongly manifest the people's belief in transmogrification, such as depicted in the following, Oboile mo tseleng ("he has returned from the road") or 
Tebello ("expectation"). In addition, Mbiti $(1990,107)$ affirms that the birth of a child is the concern not only of the parents but of many relatives, including the living and the deceased. He is not unaware of the cultural belief systems that many Africans share in common in terms of naming patterns among African families. Among typical African societies, the persistent crying of a baby signifies some problems with the given name and that the spirit world of the child does not like the name. For example, the Northern Sotho people of both Moletjie and Sekhukhune agree on the issue of a child crying for a name (Koma 2012, 73).

\section{Names about Family Circumstances}

A name expresses the psychological and emotional needs or feelings of the family. The birth of the child either coincides with a calamity that has befallen a family or with some blessings. Names may denote repeated death in the same family. For example, Dikeledi (see figure 4), meaning "tears" implies that the child was born on or after a period of mourning (Makhubedu 2009, 12). According to Makhubedu (2009, 12), most names among the Basotho people start with the prefix "Mma" meaning mother. Names like Mmabotse, Mmabatho, Mmapelo and Mmakoma are examples of such names. Mmasello, Mmalehu, Madimabe, etc., are female names that relate to bad events. The following names (figure 3 ) clearly show such a distribution in terms of meaning.

\begin{tabular}{|l|l|l|l|}
\hline Northern Sotho & Xitsonga & Tshivenda & English \\
\hline Mmalehu & - & Maemu & Mother of death \\
\hline Mahlatse & Mikateko & Mashudu & Fortune \\
\hline Dikeledi & Mihloti & Matodzi & Tears \\
\hline Lebogang & Nkhesani & Livhuweani & Be thankful \\
\hline
\end{tabular}

Figure 3: Names about family circumstances

Other names about family circumstances denote some happy moments such as Rethabile ("we are happy"), Mahlatse, Mikateko, Mashudu ("Fortune") and Lebohan, Nkhesan, /Livhuweani ("give thanks"). Other names depict some protests/bad moments in the family such as Bonang ("see or look at"), Ntumelleng ("allow me"), Tabaliatile ("there is too much or spread of the news/propaganda") and Semakale ("don't be surprised") (see Mokhathi-Mbhele 2016, 27).

\section{Bynames}

Bynames are chosen to describe an individual as well as to distinguish him or her from other individuals. Society has a tendency of exhibiting the characteristics of a community or family from which they hail. Someone once said in rhetoric, "show me your friends, and I will tell you what type of a person you are"; or "you are what you are because of what you eat." Hence, Sampson, Morenoff, and Gannon-Rowley (2002, 443-478) and Yen and Syme (1999, 387-308) could not have said it better to pen that social and economic features of neighbourhoods have been linked with mortality, general health status, disability, birth outcomes, chronic conditions, health behaviours and other risk factors for chronic disease, as well as with mental health, injuries, 
violence and other important health indicators. Rugwiji (2013) and Sacks and Warner (1996) have talked of "neighbourhood effects." Sachs and Warner $(1996,350)$ state that a country's growth also depends on the growth of the economies of neighbouring countries. Rugwiji $(2013,194)$ concurs with Sachs and Warner by reaffirming that both economic performance and political unrest of neighbouring countries in sub-Saharan Africa have some effects on the economy of the other country within the region. Mandende $(2009,18)$ agrees that one is in a better position to understand the differences that might occur in the way in which people from different areas perform their personal naming rituals. Mandende continues that even though we have indicated that the Vhavenda is a nation with one cultural system, there are differences in the way they perform their cultural activities, depending on which tribe they belong to. In that sense, it is usual that quite often, names are given in view of the demographic location of individuals. The sense of "belonging" influences naming patterns in a tremendous way, as shown in the representative examples of Motlokwa, Nhlaveng and Nethengwe, which typically denote the area where the person carrying the name hails from (see figure 4).

\begin{tabular}{|l|l|l|l|}
\hline $\begin{array}{l}\text { Northern } \\
\text { Sotho }\end{array}$ & Xitsonga & Tshivenda & English \\
\hline Motlokwa & Nhlaveng & Nethengwe & Person from Matoks \\
\hline Botlokwa & Mukalanga & Thengwe & Name of the place, Matoks \\
\hline Mohlabine & Vukalanga & Mushavhi & $\begin{array}{l}\text { Person from gaMogoboya (name of } \\
\text { place) }\end{array}$ \\
\hline
\end{tabular}

Figure 4: Bynames

\section{Occupational Names}

Occupational names are used to identify a person's trade or occupation. Musere and Byakutaga $(1999,1)$ report that occupational names may identify one with an occupation or implements used in an occupation and establish one as an associate (or relation) of a group or a person involved in an occupation. For example, "Earl" can be used either as a nickname or an occupational name for a servant employed in a noble household (Koma 2012, 15). A parent with sons and daughters engaged in various categories of occupation usually addresses them as morutiši/mudyondisi/mudededzi ("teacher"), mooki/muongori/muongi ("nurse"), or ngaka/n'anga/nanga (“doctor"). In addition, occupational names among the Zulu include Mcebisi ("The one who brings wealth"). Figure 5 below shows more examples.

\begin{tabular}{|l|l|l|l|}
\hline Northern Sotho & Xitsonga & Tshivenda & English \\
\hline Morutiši & Mudyondisi & Mudededzi & Teacher \\
\hline Mooki & Muongori & Muongi & Nurse \\
\hline Ngaka & N'anga & Nanga & Doctor \\
\hline
\end{tabular}

Figure 5: Occupational names 


\section{Nicknames}

According to Koma $(2012,43)$, nicknames are part of given names as they are not inherited at all. They can be given to a person by friends, spouses, colleagues, teachers, and by anyone else. Koma further notes that nicknames can, however, defame a person's reputation and even abuse this person emotionally. A nickname is used to describe an individual's personality, character, dress, physical appearance, or another outstanding trait. Nicknames are given to people depending on what they have done in the "public eye" - whether good or bad. For example, the late President Nelson Mandela had earned himself the name "Madiba," which is a clan name in Xhosa. Sources say that "Madiba" did not appear on his identity document. For example, in the sporting arena, the South African national team is nicknamed "Bafana Bafana." In addition, the South African rugby team has earned the nickname, Phuti (the "Springbok"). In the local football in South Africa, Sundowns Football Club is nicknamed the "Brazilians." In addition, although most African indigenous names are related to fauna and flora as well as mammals, "crocodile" and "donkey" are very rare among African last names. However, the above examples are usually given to denote typical characteristics of such animals for example, "nkwenya" or "ngwenya" (for "crocodile") "does not lose its prey between its jaws" and "pokolo", "mbongolo" or "dongi" (for "donkey") is "the beast of burden." Other familiar animal names are Nare (the "Buffalo") and Tlou (the "Elephant"), among others (Koma 2012, 2), which are common nicknames among Africans. This naming pattern (using names of animals) would concretely support Olusola's supposition about the close relationship and equality between humans and animals (Olusola 2005, 156; see also Feely 2009, 141-150). See, for example, figure 6 below.

\begin{tabular}{|l|l|l|l|}
\hline Northern Sotho & Xitsonga & Tshivenda & English \\
\hline Nkwenya & Ngwenya & Ngwenya/Koena & Crocodile \\
\hline Pokolo & Mbongolo & Dongi & Donkey \\
\hline
\end{tabular}

Figure 6: Nicknames

\section{Pseudonyms}

Pseudonyms are common among Basotho, Xitsonga and Tshivenda communities. Pseudonyms are not actually names; they are fictitious names given to individuals to protect the identity of an individual or group of people (Rugwiji 2013,23). Pseudonyms can be adopted by either an individual or groups of people, either for good or for bad. Pseudonyms can be used in different ways by different people or groups such as resistance fighters, saboteurs, gangsters, heroes, and vulnerable parties to a lawsuit, authors and actors (Lucock and Yeo 2006, 57). In qualitative research, the names of respondents are usually pseudonyms unless if by signing a letter of consent, they allow their actual names to be used for a study. Søren Kierkegaard's statement summarises it as follows:

Anonymity in our age has a far more pregnant significance than is perhaps realized; it has an almost epigrammatic significance. Not only do people write anonymously, but they write anonymously over their signature, yes, even speak 
anonymously. ... Nowadays it is possible to speak with people, and what they say is admittedly very sensible, and yet the conversation leaves the impression that one has been speaking with anonymity. (Kierkegaard 1962, 103)

\section{Circumcision Names}

Circumcision was a rite of masculine status bestowal in which man, the father, initiates a man-to-be, his son, into the covenant with God (Hoffman 1996, 2). The above definition is complemented by Mandende's $(2009,64)$ affirmation that in traditional Venda, an uncircumcised man is always regarded as a child. Mandende adds that traditionally, circumcision occurred only at initiation schools, and an uncircumcised man was not allowed to participate in community activities. ... This compelled parents to send their children to these schools. After circumcision, praise names are given to initiates (Makhubedu 2009, 33), which is always accompanied by celebrations (Mphela 2010, 53). Perhaps the circumcision praise name gives the initiate a new status. Initiation is considered a transitional stage. It is considered an important stepping stone. Mphela $(2010,52)$ affirms that an initiation school can also be described as a circumcision school wherein the initiates undergo certain instruction.

\section{Teknonymous Names}

A teknonymy is a term that refers to a name given in a situation where a father, mother or grandparent is addressed by the personal name of his or her child or grandchild (Mandende 2009, 53; Guma 2001, 272). The use of teknonymous names inculcates respect. The use of teknonymous names encourages a system of cultural respect. For example, among the Basotho, a new bride is usually given a teknonymous name so that the in-laws avoid addressing her or referring to her by her maiden name (Mohome 1972, 181, cited in Guma 2001, 272). A teknonymous name is given to a new bride immediately after being married, regardless of either having a child or not. Guma (2001, 272) explains that among the Basotho, when the woman gives birth to her first child, she is now referred to as "Mother of so-and-so" as in Mme wa Pule ("mother of Pule") and her husband "Father of so-and-so" as in Ntate wa Pule ("father of Pule"), respectively. Hence, Anim (1993, cited in Mandende 2009, 53) affirms that from the day on which a child is shown to other members of the family and a name has been bestowed, the father and the mother may assume the name of the child. See figure 7.

\begin{tabular}{|l|l|l|l|}
\hline Northern Sotho & Xitsonga & Tshivenda & English \\
\hline Mokgonyana & Mukon'wana & Mukwasha & Son-in-law \\
\hline Rangwane & Papa'ntsogo & Khotsimunene & Uncle \\
\hline Rakgadi & Hahani & Makhadzi & Aunt \\
\hline Ngwetši & N'wingi & Matswale & Daughter-in-law \\
\hline
\end{tabular}

Figure 7: Teknonymous names 


\section{Conclusion}

This study has explored names and naming patterns among three South African ethnic groups, namely, Northern Sotho, Xitsonga and Tshivenda. It was demonstrated that names and naming patterns are fascinating subjects that vary from community to community. It was shown that naming patterns tell a lot about an individual, society or country. In many cultures, names are chosen precisely because of their meaning for an individual, circumstances in the family or society where one hails from. In addition, the essay showed that names have much to do with self, identity and personal dignity. A name defines a person, how they are perceived and how they perceive themselves. It was discussed that names tell us much about gender, religion, class, nationality and ethnic origin. Although some distortions have occurred in terms of "Westernising" African cultural practices in which the missionary church played a leading role, those who have acquired new statuses because of the name change may not need to change it unless it is necessary. However, given names such as Malehu (Northern Sotho) and Maemu (Tshivenda) for "mother of death" as well as Dikeledi (Northern Sotho), Mihloti (Xitsonga) and Matodzi (Tshivenda) for "tears" may need to be reconsidered whether they are still relevant at some stage in the life of the name holder, because family circumstances which had motivated such naming patterns, may have changed.

\section{References}

Anim, N. O. 1993. Names as a Factor in Cultural Identity among the Akan: Ga and Ewe of Ghana. Pretoria: Centre for Development Analysis.

Appiah, B. 2010. “African Names: A Guide for Editors.” Features 13 (1): 15-17.

Arowolo, D. 2010. "The Effects of Western Civilization and Culture on Africa." Afro Asian Journal of Social Sciences 1 (1): 1-13.

Borkfelt, S. 2011. "What's in a Name? Consequences of Naming non-Human animals." Animals 1: 116-125. https://doi.org/10.3390/ani1010116.

Campbell, M., and T. Campbell. 1996. "Behind the Name." Accessed November 7, 2017. http://www.behindthename.com/name/michael.

Chitando, E. 2001. "Beyond Phenomenology: Teaching African Traditional Religions in a Zimbabwean University." ZJER 13 (2): 177-195. https://doi.org/10.4314/zjer.v13i2.25999.

Dreyer, Y. 2001. "Son-of-God Traditions in the Synoptic Gospels: Ferdinand Hahn's Diachronic Perspective." HTS 57 (1\&2): 506-539.

https://doi.org/10.4102/hts.v57i1/2.1878.

Feely, J. M. 2009. "IsiXhosa Names of South African Land Mammals." African Zoology 44 (2): 141-150. https://doi.org/10.1080/15627020.2009.11407448. 
Frankel, R. M., K. J. Devers, and J. Kelly. 2000. "Qualitative Research: A Consumer Guide.” Change and Practice 13 (1): 1-8. https://doi.org/10.1080/135762800110664.

Guma, M. 2001. "The Cultural Meaning of Names among Basotho of Southern Africa: A Historical and Linguistic Analysis.” Nordic Journal of African Studies 10 (3): 265-279.

Haber, H. 2001. “Theophoric Names in the Bible.” Jewish Bible Quarterly 29 (1).

Hahn, F. 1974. Christologische Hoheitstitel: Ihre Geschichte im Frohen Christentum. 4. Aufl. Gottingen: Vandenhoeck and Ruprecht.

Hanks, P. (n.d.). “General Information.” Accessed November 7, 2017. http://www.casa.ucl.ac.uk/surnames/papers/Hanks_background.pdf. https://doi.org/10.1057/978-1-137-45344-0_1.

Hoffman, L. A. 1996. Covenant of Blood. Chicago: University of Chicago.

Jobling, A. M. 2001. "In the Name of the Father: Surnames and Genetics." Trends in Genetics 17 (6): 353-357. https://doi.org/10.1016/S0168-9525(01)02284-3.

Kierkegaard, S. 1962. The Present Age. New York: Harper Torchback.

Knight, D., and A-J. Levine. 2011. The Meaning of the Bible: What the Jewish Scriptures and Christian Old Testament Can Teach us, 1st edition. New York: Harper One.

Koma, H. M. 2012. "An Analysis of Given and Inherited Names among the Northern Sotho Speaking People in Moletjie and Sekhukhune: Limpopo Province: An Onomastic Perspective.” MA dissertation. University of Limpopo.

Liddel, H. G., and R. Scott. 1953. Greek-English Lexicon, 9th edition. Oxford: Oxford University Press.

Lucock, C., and M. Yeo. 2006. "Naming Names: The Pseudonym in the Name of the Law." University of Ottawa Law and Technology Journal 3 (1): 53-108.

Makhubedu, M. G. 2009. "The Significance of Traditional Names among the Northern Sotho Speaking People Residing within the Greater Baphalaborwa Municipality in the Limpopo Province.” Master's dissertation. University of Limpopo.

Mandende, I. P. 2009. “A Study of Tshivenda Personal Names.” PhD thesis. University of South Africa.

Mbiti. J. S. 1990. African Religions and Philosophy, second revised and enlarged edition. London: Heinemann.

Mohome, P. M. 2013. "Naming in Sesotho: Its Sociocultural and Linguistic Basis.” A Journal of Onomastics 20 (3): 171-185. https://doi.org/10.1179/nam.1972.20.3.171. 
Mohome, P. M. 1972. Naming in Sesotho: Its Socio-cultural and Linguistic Basis. New York: University College. https://doi.org/10.1179/nam.1972.20.3.171.

Mokhathi-Mbhele, M. M. L. 2016. "Describing Sesotho Names as Clause Complexes in Social Discourse: A Systemic Functional Linguistic Approach.” International Journal of English Language and Translation Studies 4 (4): 21-38.

Mphela, K. L. 2010. “An Analysis of Personal Naming in Moletjie Area of the Limpopo Province: An Onomastic Approach.” MA dissertation. University of Limpopo.

Musere, J., and S. C. Byakutaga. 1999. African Names and Naming. Los Angeles: Ariko Publications.

Mutunda, S. 2016. "Luvabe Personal Names and Naming Practices: A Socio-cultural Analysis.” International Journal of Education: Culture and Society 1 (3): 75-81.

Neethling, B. 2003. "Perceptions around the English Name of Xhosa Speakers." Nomina Africana 17 (2): 47-65.

Neethling, B. 2004. "Name Choices among the Xhosa of South Africa." The Language Quarterly XXIX (4): 1-32.

Nyambi, O., T. Mangena, and C. Pfukwa (Eds). 2016. The Postcolonial Condition of Names and Naming Practices in Southern Africa. Newcastle: Cambridge Scholars Publishing.

Olusola, A. G. 2005. “Animals in the Traditional Worldview of the Yoruba." Folklore 30: 155-172. https://doi.org/10.7592/FEJF2005.30.olusala.

Olatunji, A., and M. Issah. 2015. "Personal Name as a Reality of Everyday Life: Naming Dynamics in Select African Societies." The Journal of Pan African Studies 8 (3): 72-90.

Pelczar, W. M. 2001. "Names as Tokens and Names as Tools.” Synthese 128: 133-155. https://doi.org/10.1023/A:1010304825913.

Rugwiji, T. 2013. “Appropriating Judean Postexilic Literature in a Postcolonial Discourse: A Case for Zimbabwe.” PhD thesis. University of South Africa.

Rugwiji, T. 2014. "The Salvific Task of the Suffering Servant in Isaiah 42: 1-7: A Contemporary Perspective.” Journal for Semitics 23 (2): 289-314. https://doi.org/10.25159/1013-8471/3492.

Sachs, J. D., and A. M. Warner. 1996. "Sources of Slow Growth in African Economies." Journal of African Economies 6 (3): 335-376. https://doi.org/10.1093/oxfordjournals.jae.a020932.

Sampson, R., J. Morenoff, and T. Gannon-Rowley. 2002. “Assessing 'Neighbourhood Effects': Social Processes and New Directions in Research." Annual Review of Sociology 28:443478. https://doi.org/10.1146/annurev.soc.28.110601.141114. 
Scott, E. S. 2004. "Marriage, Cohabitation and Collective Responsibility for Dependency." University of Chicago Legal Forum 1 (7): 225-264.

Smith-Bannister, S. 1997. Names and Naming Patterns in England: 1538-1700. Oxford: Clarendon Press. https://doi.org/10.1093/acprof:oso/9780198206637.001.0001.

Smith, D. S. 1974. "Child-naming Practices as Cultural and Familial Indicators.” Local Population Studies 32: 17-27.

Suzman, S. M. 1994. "Names as Pointers: Zulu Personal Naming Practices.” Language in Society 23: 253-72. https://doi.org/10.1017/S0047404500017851.

Tonkin, E. 1980. "Jealousy Names: Civilised Names: Anthroponomy of the Jlao Kru of Liberia.” Man 15: 643-64. https://doi.org/10.2307/2801538.

Waters, J. J. 1984. "Naming and Kinship in New England: Guilford Patterns and Usage, 16931759." New England Historical and Genealogical Register 138: 161-162.

Wilson, S. 1998. The Means of Naming: A Social and Cultural History of Personal Names in Western Europe. Bristol: Penn: ULC Press.

Yen, I., and S. L. Syme. 1999. "The Social Environment and Health: A Discussion of the Epidemiologic Literature.” Annual Review of Public Health 20: 287-308. https://doi.org/10.1146/annurev.publhealth.20.1.287. 